\title{
Iranian propolis efficiently inhibits growth of oral streptococci and cancer cell lines
}

\author{
Fariba Asgharpour ${ }^{1,2}$, Ali Akbar Moghadamnia ${ }^{3,4}$, Ebrahim Zabihi ${ }^{5}$, Sohrab Kazemi ${ }^{5}$, \\ Amirmorteza Ebrahimzadeh Namvar ${ }^{6}$, Hemmat Gholinia ${ }^{7}$, Mina Motallebnejad ${ }^{8^{*}}$ and Hamid Reza Nouri ${ }^{5^{*}}$ (D)
}

\begin{abstract}
Background: Propolis is a natural bee product with a wide range of biological activities that are related to its chemical composition. The present study investigated the quantification of quercetin $(\mathrm{Q})$ in Ardabil ethanol extract of propolis (AEEP), and then compared its anti-bacterial, anti- biofilm and cytotoxic effects on cancer and normal cell lines.
\end{abstract}

Method: In the present study, the chemical composition of AEEP was determined through the high-performance liquid chromatography (HPLC). The AEEP and its main component, quercetin (Q), were evaluated in vitro against 57 oral streptococci by a broth micro-dilution method. The biofilm formation was assessed through the crystal violet staining and MTT assays. The impact of AEEP and Q anti-proliferative effect were evaluated on the fibroblast as normal and cancer cell lines (KB and A431).

Results: The Q concentration in the composition of AEEP was $6.9 \%$ of all its components. The findings indicated that the AEEP and Q were efficient against the cariogenic bacteria and were able to inhibit the S.mutans biofilm adherence at a sub-MIC concentration. Moreover, electron micrographs indicated the inhibition of biofilms compared to control biofilms. In addition, the AEEP and Q indicated a dose-dependent cytotoxic effect on A431 and KB cell lines. On the contrary, they had no cytotoxic effect on fibroblast cells.

Conclusion: The results indicated that the synergistic impact of main components of AEEP was related to the inhibition of the cancer cell proliferation, cariogenic bacteria and oral biofilm formation. It may play a promising role in the complementary medicine and, it is suggested to be used as food additives.

Keywords: Anti-bacterial, Anti-biofilms, Propolis, Quercetin

\section{Background}

The propolis is a nontoxic natural resinous substance that is produced by honeybee from diverse plants containing several chemical compounds such as flavonoids, phenolic acids, and aromatic compounds [1,2]. The ingredient of this compound depends on its geographic origin and other factors such as collection periods by honeybees [3]. Propolis has a wide range of biological functions such as anti-microbial, anti-viral, anti-fungal, anti-inflammatory, anti-oxidative, free-radical scavenging and anti-tumor properties [2-6]. The anti-microbial

\footnotetext{
* Correspondence: minamotalebnejad96@gmail.com; nourihr851@gmail.com ${ }^{8}$ Oral Health Research Center, Health Research Institute, Babol University of Medical Sciences, Babol, Iran

${ }^{5}$ Cellular and Molecular Biology Research Center, Health Research Institute, Babol University of Medical Sciences, Babol, Iran

Full list of author information is available at the end of the article
}

activity of propolis is considerable and it varies according to the flavonoid content [7]. The reduction of bacterial count in oral cavity effectively prevents the teeth decay [8]. Streptococcus mutans, a main acidogenic bacterium, is crucial in developing malignant cariogenesis [9]. Due to the synthesis of extracellular polysaccharides, mainly water-insoluble glucan, S. mutans can be colonized on the teeth surface and can initiate the plaque formation and dental caries [10]. Propolis can adhere to the teeth surface, and subsequently decrease the dental plaque development [11-13]. According to the emergence of multidrug resistant strains, the reduction and elimination of the pathogenic bacteria and also maintaining the normal flora are critical to prevent the teeth decay and oral diseases [14].

(c) The Author(s). 2019 Open Access This article is distributed under the terms of the Creative Commons Attribution 4.0 International License (http://creativecommons.org/licenses/by/4.0/), which permits unrestricted use, distribution, and reproduction in any medium, provided you give appropriate credit to the original author(s) and the source, provide a link to the Creative Commons license, and indicate if changes were made. The Creative Commons Public Domain Dedication waiver (http://creativecommons.org/publicdomain/zero/1.0/) applies to the data made available in this article, unless otherwise stated. 
Recent studies indicate that ethanol extract of propolis (EEP) exerts potent anticancer activities against many tumor cells. The results revealed anticancer properties of propolis via various mechanisms such as the inhibition of cell proliferation and growth, induction of apoptosis, cell cycle arrest and induction of mitochondrial stress. Propolis contains a wide range of polyphenol and flavonoid content that strongly depends on the geographical areas, time and place of collection, climate, and the surrounding vegetation. This wide spectrum of different factors can affect the biological activity of propolis [15].

Quercetin (3,3',4',5,7-penta hydroxyl flavanone) is a flavonoid that can be found in different types of plants; and propolis is a one of the richest flavonoid source. Quercetin has a wide range of pharmacological properties such as the anti-inflammation and anti-oxidation; hence, it can be beneficial to the human health. Previous studies on bioactive effects of quercetin revealed that it could inhibit the growth of different microorganisms, especially gram-positive bacteria (Bacillus subtilis, Micrococcus luteus, Staphylococcus aureus and Staphylococcus epidermidis) and gram negative bacilli (Escherichia coli and Pseudomonas aeruginosa) [16-19]. Quercetin applied anti-proliferative and antitumor activities via various mechanisms such as cell cycle arrest during G0/G1 or $\mathrm{G} 2 / \mathrm{M}$ phases of the cell cycle in leukemia, breast carcinoma and esophageal adenocarcinoma cells [20-22]. The present study aimed to investigate the quantification of quercetin $(\mathrm{Q})$ in the Ardabil ethanol extract of propolis (AEEP), and then compared its anti-bacterial, antibiofilm and cytotoxic effects on cancer and normal cell lines with AEEP.

\section{Methods}

\section{Preparation of Ethanolic extract of propolis}

Parts of crude propolis produced by Apis mellifera bees were collected in the spring of 2016 from Ardabil in Northern of Iran. $2 \mathrm{~g}$ of propolis dissolved with $25 \mathrm{ml}$ ethanol and shacked for 2 days at room temperature. Then, it was filtered and kept in the dark place. A rotary vacuum evaporator used for ethanol removal. The ethanol extract of propolis had a brown color and extracts stored at $-20^{\circ} \mathrm{C}$.

High-performance liquid chromatography (HPLC) analysis The propolis sample was analysis by HPLC consisted a chromatograph equipped with a UV detector (Knauer, Germany) and a normal-phase silica column $(250 \mathrm{~mm} \times$ $4 \mathrm{~mm}, 5 \mu \mathrm{m}$ particle diameter, Eurospher C18m, Altmann Analytik, Germany) [23]. Quercetin was used as standard. The mobile phase was a mixture of $20 \%$ acetonitrile (solvent $\mathrm{A}$ ) and $0.2 \%$ formic acids (solvent $\mathrm{B}$ ) which were previously degassed and filtrated. The analysis started for 0 to $7 \mathrm{~min}$ and increased to $60 \%$ for
7-10 min, was kept a $90 \%$ for $10-12 \mathrm{~min}$. The column temperature was set at $25^{\circ} \mathrm{C}$ with a constant $0.8 \mathrm{ml} / \mathrm{min}$ flow. $20 \mu \mathrm{l}$ of the quercetin as standard and sample solution was injection and the chromatograms were integrated at $270 \mathrm{~nm}$.

\section{Bacterial strains}

The plaque samples were collected with swab from the tooth surface in different age groups that referred to Department of Oral and Maxillofacial Medicine at Babol University of Medical Sciences, in 2017. The swabs were placed in a thioglycolate broth medium (Merck, Germany). Oral streptococci were isolated by Blood agar, MSB agar (mitis salivarius-bacitracin) and TYCSB agar (trypticase yeast extract cysteine sucrose with bacitracin). The plates were incubated in a jar (5\% CO2) for $24 \mathrm{~h}$ at $37^{\circ} \mathrm{C}$. Identification of oral streptococci was performed according to standard methods [24], included colony morphology, gram positive cocci, record haemolytic reactions, catalase test, fermentation of different carbohydrates and finally confirmed with Microgen Strep ID. Streptococcus mutans (ATCC 35668), Streptococcus sobrinus (ATCC 27607) and Streptococcus penumoniae (ATCC 49619) were used as control species.

\section{Minimum inhibitory concentration (MIC)}

A broth microdilution method was used to determine MIC according to CLSI broth microdilution method [24]. First, bacterial suspension $\left(10^{5} \mathrm{CFU} \mathrm{ml}^{-1}\right)$ was inoculated into CAMHB (Merck, Germany) and dispensed at in 96-well $(0.2 \mathrm{ml})$ microtiter plates. Two-fold serial dilutions of AEEP and Q were prepared and transferred to each well of the original extract in DMSO with final concentration from 1.56 to $1000 \mu \mathrm{g} / \mathrm{ml}$. Final concentration of DMSO as solvent was $1 \%$. The number of wells in each plate were allocated to negative control, a sterility control, and a control for the solvent (DMSO), the antibiotic penicillin tested as positive controls. Plates were anaerobically incubated for $24 \mathrm{~h}$ at $37^{\circ} \mathrm{C}$. MIC was determined as the lowest concentration of samples that had no macroscopically visible growth. Minimum bactericidal concentration $(\mathrm{MBC})$ was determined by subculturing of three previous wells on Mueller Hinton agar and incubating for $24 \mathrm{~h}$. The lowest concentration of samples with no bacterial growth (99\% inhibition) was reported as $\mathrm{MBC}$.

\section{Determination of anti-biofilms activity}

The anti-adhesion propertie of AEEP and Q on Streptococcus mutans (ATCC 35668) was tested in a microtitre plate biofilm assay, with some modifications [25]. Isolate was cultured in $5 \mathrm{ml}$ of $\mathrm{BHI}$ under anaerobic conditions at $37^{\circ} \mathrm{C}$ for $48 \mathrm{~h}$. To $100 \mu \mathrm{l} \mathrm{BHI}$ with $2 \%$ sucrose (w/v) containing sub-MIC of samples in each well added 
$100 \mu \mathrm{l}$ of a standardized $\left(5 \times 10^{5} \mathrm{CFU} \mathrm{ml}^{-1}\right)$ of isolate. The control well was containing only $\mathrm{BHI} /$ sucrose $(2 \% \mathrm{w} / \mathrm{v})$. After incubating the plates in anaerobic conditions at $37^{\circ} \mathrm{C}$ for $24 \mathrm{~h}$, the plates were assessed by stain with crystal violet and the biofilms metabolic activity (MTT assay).

\section{Crystal violet staining assay}

The following $24 \mathrm{~h}$ incubation, loosely attached cells were removed by three times washing of wells with PBS. After air-drying; the plates incubated in an oven at $60^{\circ} \mathrm{C}$ for $45 \mathrm{~min}$. Then, $100 \mu \mathrm{l}$ of crystal violet $1 \%(\mathrm{w} / \mathrm{v})$ was added to each well and were placed at room temperature for $15 \mathrm{~min}$. The wells were washed 3-4 times with sterile distilled water to remove unabsorbed stain. Biofilm formation was evaluated by adding $125 \mu \mathrm{l}$ of $\% 95$ ethanol to destain the wells. The absorbance at $590 \mathrm{~nm}$ was determined using a microplate reader (Rayto, RT- 2100C, Chinese). The percentage of inhibition was calculated for each concentration of the samples by the following formula: [(OD control- OD sample)/ OD control $] \times 100$.

\section{MTT assay}

MTT was dissolved in PBS to obtain a concentration of $5 \mathrm{mg} / \mathrm{ml}$. Following remove and dried plates, the wells was filled with $100 \mu \mathrm{l}$ of MTT solution and incubated for $3 \mathrm{~h}$ at $37^{\circ} \mathrm{C}$. The produced formazan was dissolved with add $150 \mu \mathrm{l}$ of DMSO. The Optical density (OD) of each well was read by a microplate reader (Rayto, RT$2100 \mathrm{C}$, Chinese) at $570 \mathrm{~nm}$. The percentage of inhibition were calculated by the following formula: [(OD controlOD sample)/ OD control] $\times 100$.

\section{Scanning electron microscopy}

For SEM analysis, the wells were washed with PBS and then fixed with a $4 \%$ glutaraldehyde solution for $24 \mathrm{~h}$. The biofilms were dehydrated using a series of ethanol (50, 70, 90, and $100 \%$ ) and dried for $24 \mathrm{~h}$. The specimens sputter was coated with gold-palladium. The samples were analyzed by scanning electron microscopy (SEM; SNE- 4500 M, SEC CO., LTD, Suwon, Korea) [26].

\section{Cell cultures and cytotoxicity analysis}

The cytotoxic effect of AEEP and Q was tested on normal human fibroblast and cancer cell lines including the mouth epidermoid carcinoma (KB) and skin squamous cell carcinoma (A431). KB and A431 cell lines was obtained from the National Cell Bank of Iran, Pasteur Institute (Tehran, Iran) and was cultured in RPMI 1640 containing L-glutamin and supplemented with $10 \%$ Fetal calf serum (FBS), and 1\% PenStrep (penicillin G $100 \mathrm{IU} /$ $\mathrm{ml}$, streptomycin $100 \mu \mathrm{g} / \mathrm{ml}$ ). Fibroblast was isolated as previously described. Briefly, fibroblast cells were isolated from human 1-3 months newborn foreskins that underwent routine circumcision in Amirkola Children Hospital, Babol/ Iran. The Ethics Committee of Babol University of Medical Science previously approved isolation of fibroblast [27]. Fibroblast cells were cultured in Dulbecco's Modified Eagle Medium (DMEM); (Biowest, USA), 10\% Fetal bovine serum (FBS) and 1\% Lglutamine $2 \mathrm{mM}$ with penicillin $(100 \mathrm{U} / \mathrm{ml})$ and streptomycin $(100 \mu \mathrm{g} / \mathrm{ml})$. The cell lines were grown as monolayers in $25 \mathrm{~cm} 2$ cell culture flasks at $37^{\circ} \mathrm{C}$ in a $5 \%$ $\mathrm{CO} 2$ humidified atmosphere. Cells were treated with 0 up to $200 \mu \mathrm{g} / \mathrm{ml}$ of AEEP and Q. Each concentration was tested in triplicates along with the control group.

The cytotoxic effect was measured using the MTT assay after $48 \mathrm{~h}$ incubation with AEEP and Q. To determine the cell viability, $50 \mu \mathrm{l}$ of MTT solution in PBS (5 $\mathrm{mg} / \mathrm{ml}$ ) was added cells were incubated for an extra time $4 \mathrm{~h}$. Then, the insoluble formazan product was dissolved in $150 \mu \mathrm{l}$ DMSO, and then the OD was measured using a microplate reader (Rayto, RT-2100C, Chinese) at 540 $\mathrm{nm}$ [25]. The obtained OD from the control group was considered as $100 \%$ viability.

\section{Statistical analysis}

Data were analyzed using GraphPad Prism v 6.07 (GraphPad Software Inc., La Jolla, CA, USA). Results were expressed as the mean $\pm \mathrm{SD}$. Comparisons between groups was performed via $t$-student tests and, the one-way ANOVA. $P<0.05$ was considered statistically significant.

\section{Results}

\section{HPLC analysis}

Based on calibration curves of the HPLC analysis, which was evaluated for standard Q, the concentration of this bioactive compound was determined in propolis. For quantification, acetonitrile and formic acids were used as the mobile phase. Identified and quantified quercetin was performed on the basis of the spectrum correlation with standard quercetin at $270 \mathrm{~nm}$ (Fig. 1). The Q concentration in the the composition of AEEP was $6.9 \%$ of all its total components.

\section{Antibacterial assay}

Oral streptococci $(n=57)$, which was obtained from the culture included S. salivarius $(n=20), S$. mutans $(n=20)$, Streptococcus oralis $(n=3)$, Streptococcus mitis biovar $1(n=4)$, Streptococcus uberis $(n=5)$, Streptococcus bovis $(n=3)$, Steptococcus equinus $(n=1)$ and Streptococcus parasanguinis $(n=1)$.

\section{Minimum inhibitory concentration (MIC)}

Table 1 presents MIC values for AEEP and Q against 57 oral streptococci and standard strains. The lowest MIC 


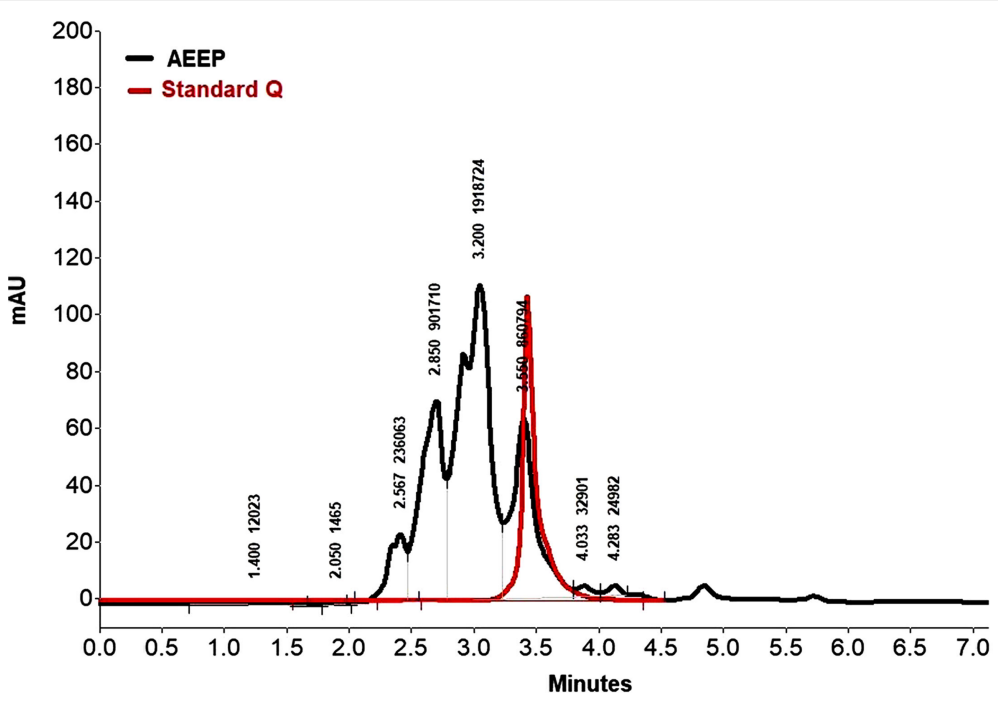

Fig. $1 \mathrm{HPLC}$ analysis of quercetin (red graph) and ethanolic extract of propolis (AEEP) that represented in black color

value belonged to S. Salivarius, which was treated with AEEP, and the highest MIC belonged to Streptococcus penumoniae (ATCC 49619) treated with Q. AEEP inhibited the growth of oral streptococci with MIC values from 3.12 to $100 \mu \mathrm{g} / \mathrm{ml}$. Penicillin inhibited oral streptococci with MIC values of $0.078-20 \mu \mathrm{g} / \mathrm{ml}$. In most of isolates, MBC values of samples were 1 to 5 times higher than MIC values.

\section{Biofilm formation by Streptococcus mutans}

Figure 2 indicted the anti- biofilm effect of AEEP and $\mathrm{Q}$ at $24 \mathrm{~h}$ of growth phases of biofilm in $\mathrm{CV}$ and MTT methods. The percentage of adherent cells at concentration of sub-MIC of treatments significantly decreased at $24 \mathrm{~h}$ of the biofilm growth $(p<0.001)$ compared to control-biofilms. The maximum reduction in biofilm formation was estimated at 76 and $56 \%$ in CV method and 71 and $44 \%$ in MTT method in the presence of AEEP $(6 \mu \mathrm{g} / \mathrm{ml})$ and Q $(20 \mu \mathrm{g} / \mathrm{ml})$ respectively compared to the control. According to these findings, the most significant reduction was observed by AEEP. On the other hand, there was a significant difference between $\mathrm{CV}$ and MTT methods in the presence of Q. As shown in the Fig. 3, there are clear effects of AEEP and Q on the activity of $S$. mutans by scanning the electron microscopy. The control sample (Fig. 3a), showed biofilm formation after $24 \mathrm{~h}$, while the number of cells decreased in the treated wells in sub-MIC (Fig. $3 b$ and c).

Table 1 The Minimum Inhibitory Concentration (MIC) values of samples against oral Streptococci (values in $\mu \mathrm{g} / \mathrm{ml}$ )

\begin{tabular}{|c|c|c|c|c|c|c|}
\hline \multirow[t]{2}{*}{ Oral streptococci } & \multicolumn{2}{|l|}{ AEEP } & \multicolumn{2}{|l|}{ Quercetin } & \multicolumn{2}{|l|}{ Penicillin } \\
\hline & MIC & $\mathrm{MBC}$ & MIC & MBC & MIC & $\mathrm{MBC}$ \\
\hline Streptococcus salivarius (20) & $3.12-25$ & $50-100$ & $50-100$ & $200-400$ & $0.078-2.5$ & $0.31-5$ \\
\hline Streptococcus mutans (20) & $6.25-25$ & $50-100$ & $50-200$ & $100-400$ & $0.078-0.31$ & $0.31-0.62$ \\
\hline Streptococcus mitis biovar1(4) & $6.25-12.5$ & 50 & $25-100$ & 200 & $0.62-1.25$ & $1.25-2.5$ \\
\hline Streptococcus parasanguinis(1) & 25 & 200 & 100 & 400 & 0.31 & 0.62 \\
\hline Streptococcus uberis (5) & 25 & 100 & $100-200$ & $200-400$ & $1.25-2.5$ & $2.5-5$ \\
\hline Streptococcus bovis (3) & 12.5 & 50 & 100 & 200 & $1.25-2.5$ & $2.5-5$ \\
\hline Streptococcus equinus (1) & 12.5 & 100 & 100 & 200 & 2.5 & 5 \\
\hline Streptococcus oralis (3) & 25 & 50 & $50-100$ & 200 & $5-10$ & 10 \\
\hline Streptococcus mutans ATCC 35668 Streptococcus & 12.5 & 100 & 50 & 200 & 2.5 & 10 \\
\hline sobrinus ATCC 27607 & 25 & 100 & 100 & 200 & 2.5 & 10 \\
\hline Streptococcus penumoniae ATCC 49619 & 100 & 200 & 200 & 400 & 20 & 80 \\
\hline
\end{tabular}




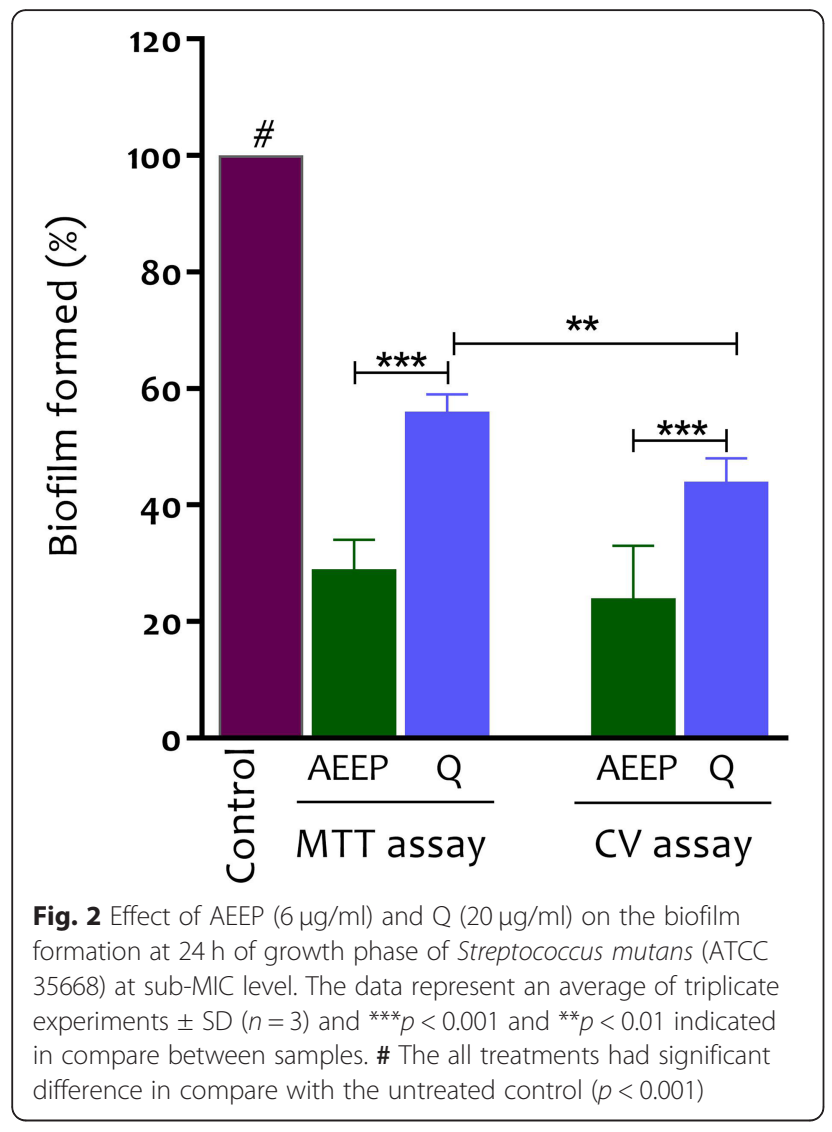

\section{AEEP and Q had cytotoxic effects on A431 and KB, but not on fibroblast cells}

Figure 4 shows results of the cell incubation in the presence of $25-200 \mu \mathrm{g} / \mathrm{ml}$ of AEEP and Q after $48 \mathrm{~h}$. AEEP and $\mathrm{Q}$ had cytotoxic effects on A431 and KB cell lines in a dose-dependent manner. $\mathrm{IC}_{50}$ values of $\mathrm{AEEP}$ and $\mathrm{Q}$ on KB cell line were $40 \pm 8.9 \mu \mathrm{g} / \mathrm{ml}$ and $195 \pm 14.9 \mu \mathrm{g} / \mathrm{ml}$ respectively after $48 \mathrm{~h}$ of incubation. The significant difference was observed between control and different concentrations of AEEP and Q $(p<0.001)$. On the contrary, 25 and $50 \mu \mathrm{g} / \mathrm{ml}$ of $\mathrm{Q}$ showed no significant difference with the control. As shown in Fig. 4a, a significant different was observed between AEEP and $Q$ in each tested concentration. $\mathrm{IC}_{50}$ values of $\mathrm{AEEP}$ and $\mathrm{Q}$ were $98 \mu \mathrm{g} / \mathrm{ml}$ and $195 \mu \mathrm{g} / \mathrm{ml}$ respectively on the A431 cell line (Fig. 4b). Furthermore, a significant difference was observed between the control and 100 and $200 \mu \mathrm{g} / \mathrm{ml}$ of AEEP and $\mathrm{Q}(p<0.001)$. In conclusion, the AEEP showed the highest cytotoxicity on targeted cancer cell lines. On the other hand, $25-200 \mu \mathrm{g} / \mathrm{ml}$ of both AEEP and $\mathrm{Q}$ tended to increase fibroblast cells count after 48 $\mathrm{h}$, but there were no statistical significant difference $(p>$ 0.05) with the control (Fig. 4c). The percentage of cell viability between AEEP and Q was not statistical significant in all tested doses $(p>0.05)$.

\section{Discussion}

Propolis has a considerable variety of biological properties and therapeutic activity. It is relatively non-toxic and indicated anti-microbial activity against several bacteria, in particular, oral pathogens [28] and it is likely to directly affect the microorganisms (in vitro) and may activate mechanisms that are involved in killing microorganisms by stimulating the immune system (in vivo) [29]. Propolis has been taken into account in many studies in terms of dentistry to be beneficial in oral health including dental caries prevention, inhibiting the oral cancer growth, periodontal diseases, plaque formation and decreasing the incidence of oral mucositis after chemotherapy and it acts as the anti-inflammatory agent [2]. The biological activity of propolis is related to its origin such as the content of phenols and flavonoids. Flavonol quercetin (Q) is wellknown in flavonoids. According to recent studies, Q indicates a wide range of pharmacological properties especially anti-cancer effects and anti-bacterial activity $[30,31]$. In the present study, we examined effects of AEEP (containing $10.56 \mu \mathrm{g} / \mathrm{mL}$ of $\mathrm{Q}$ that was detected in HPLC analysis) and Q on inhibiting the growth of oral streptococci and studied their anti-tumor efficacy.

AEEP inhibited the growth of oral streptococci with MIC values ranging from 3.12 to $100 \mu \mathrm{g} / \mathrm{ml}$. The
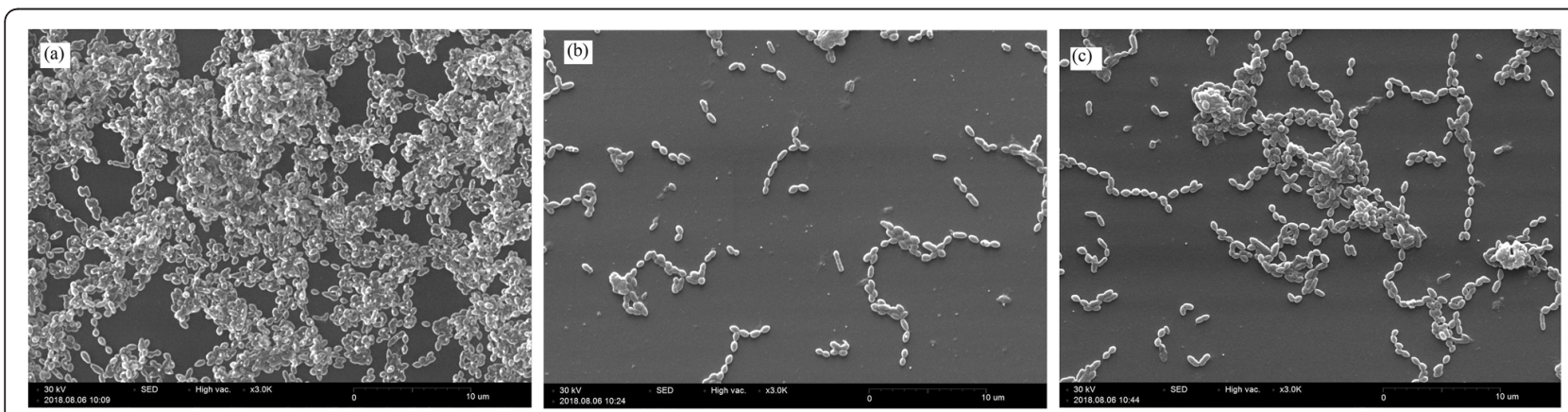

Fig. 3 The scanning electron micrograph of Streptococcus mutans (ATCC 35668) biofilm formed after $24 \mathrm{~h}$ of incubation. a Control and in the presence of sub- MIC levels of b AEEP $(6 \mu \mathrm{g} / \mathrm{ml})$, c Q $(20 \mu \mathrm{g} / \mathrm{ml})$ 

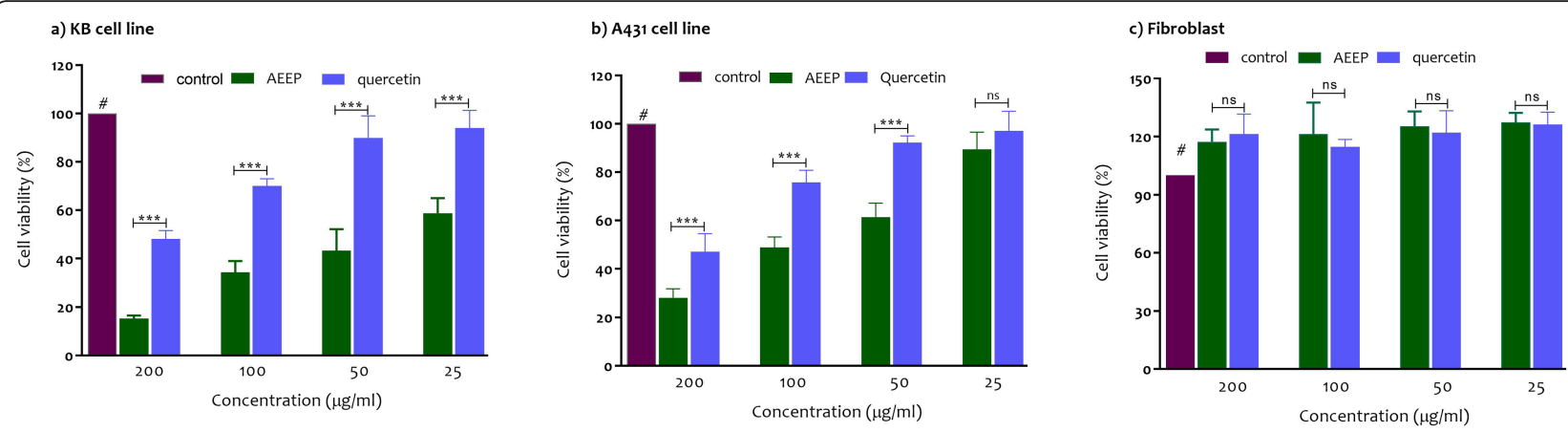

Fig. 4 The percentage of cell viability by MTT exclusion on Mouth epidermoid carcinoma cell (KB) cells (a), skin squamous cell carcinoma (A431) cells $(\mathbf{b})$ and fibroblast cell lines (c). Data are expressed as mean $\pm \mathrm{SD}(n=3)$. ${ }^{* *} p<0.001$ and ${ }^{* *} p<0.01$ indicated in compare between samples. \# There was no significant difference between control with Q $50 \mu \mathrm{g} / \mathrm{ml}$ and Q $25 \mu \mathrm{g} / \mathrm{ml}$ in KB, $50 \mu \mathrm{g} / \mathrm{ml}$ and $25 \mu \mathrm{g} / \mathrm{ml}$ of AEEP and Q in A431 and the all concentrations of AEEP and $\mathrm{Q}$ in fibroblast cell lines $(p<0.05)$

obtained results were similar to the Tunisian propolis on oral streptococci with MIC values ranging from 2 to > $512 \mu \mathrm{g} / \mathrm{ml}$ [25], Brazilian propolis on dental caries ranging from 25 to $400 \mu \mathrm{g} / \mathrm{ml}$ [32]. Geopropolis (EEGP) also inhibited the growth of S. mutans UA 159 at concentrations lower than $50 \mu \mathrm{g} / \mathrm{ml}$ and reported that extracts were considered promising when MIC value was below $500 \mu \mathrm{g} / \mathrm{ml}$; and this result was consistent with the present study [11].

The results indicated that $\mathrm{Q}$ inhibited the growth of streptococci strains at concentrations of 25 to $200 \mu \mathrm{g} /$ $\mathrm{ml}$, whereas up to $100 \mathrm{mg} / \mathrm{ml}$ of $\mathrm{Q}$ and its esters in a study by Gatto et al.; indicated no effect on tested microorganisms [31]. On the contrary, Woźnicka et al. indicated that Q with MIC values of $6.25 \mu \mathrm{g} / \mathrm{ml}$ was able to inhibit all strains; and NaQSA (sodium salt of quercetin-5í-sulfonic acid) reduced MIC values of $S$. aureus ATCC 29213 to $3.9 \mu \mathrm{g} / \mathrm{ml}$ and indicated that structures of drugs were related to their biological properties [33].

In most oral streptococci, glucans include extracellular thin layers that are produced in the presence of sucrose leading to the adhesion and biofilm formation of dental plaque. The formation of biofilms requires the initial binding of bacteria to a single surface and occurs in the subsequent bacterial population [34]. Propolis contains natural bioactive compounds and is effective in reducing oral biofilm bacteria [25]. In the present study, two methods were used to evaluate the anti-biofilm effects of AEEP and Q on S. mutans according to the MTT assay (a colorimetric assay for determining the cell metabolic activity) and the crystal violet assay (a simple method for staining attached cells). Both methods indicated good anti-biofilm activities of compounds that inhibited the biofilm formation. Chilean propolis affected the biofilm formation by S. mutans by an inhibition of 50\% [9]. The EEPG inhibited the adherence of $S$. mutans growing cells at sub-MIC concentrations with a rate of $51 \%$ at $25 \mu \mathrm{g} /$ $\mathrm{ml}$ [11]. On the contrary, Tunisian propolis inhibited the oral biofilm at a concentration of higher than MIC compared to other studies [25]. According to reports, Quercetin inhibited the anti-biofilm activity against bacterial pathogens such as Pseudomonas aeruginosa [16, 17], Staphylococcus aureus [18], Streptococci mutans [26] and Listeria monocytogenes [19] indicating that Q had a potential of controlling the biofilm formation and may inhibit biofilm through specific mechanisms such as the initial adhesion or production of extracellular polymeric substances [19]. Therefore, the biofilm inhibitory effect of $\mathrm{Q}$ in the present study might be through similar mechanisms. Furthermore, Hasan et al. indicated that the maximum reduction in biofilm formation was at 24 $\mathrm{h}$ of the growth phases in the presence of $\mathrm{Q}$; and the most significant reduction was seen by the combination of $\mathrm{Q}$ and Deoxynojirimycin compared to the control [26].

AEEP and Q inhibited the growth of $\mathrm{KB}$ and $\mathrm{A} 431$ cancer cells in a dose-dependent manner, but they had no effect on fibroblast cells compared to the control. Propolis solvent had no effects on viable cells; and the cytotoxic effects were solely due to propolis components. Due to reported side effects of surgery, radiotherapy and chemotherapy in the cancer treatment process, there has been increasing interest in the research on natural products, which were effective in the cancer prevention [30]. Propolis is a natural source with cytotoxic effects on different cell lines. In this regard, Tunisian propolis has a cytotoxic effect on Raw 264.7 cells, epithelial cell line (Hep-2), the respiratory epithelial cell line (A549), the intestinal epithelial cell line (HT-29) and normal human fibroblast-like fetal lung cell line (MRC-5) in a dose- and time-dependent procedure [25]. Moreover, the Brazilian propolis inhibited the growth of tumor cells and showed an anti-cancer potential [35]. The study on the Iranian propolis on the gastric cancer in rats revealed the chemoprotective effect on MNNG-initiated gastric cancer 
through inhibiting the cell proliferation and apoptosis induction [36]. Najafi et al. studied water extracts of the Iranian propolis (WEP) on cancer and normal cell lines. Furthermore, WEP comprised only the soluble part of propolis, but it was able to inhibit the growth of cancer cells and stimulate the growth of normal cells up to $60 \%$ compared with the control [37]. Effect of 25 to $800 \mu \mathrm{g} / \mathrm{ml}$ of the Iranian propolis extracts was evaluated on the viability of L929 fibroblast cells and did not show any cytotoxicity in $\leq 200 \mu \mathrm{g} / \mathrm{ml}$; however, the viability was reduced to $20-50 \%$ at $400-800 \mu \mathrm{g} / \mathrm{mL}$ [38]. The results indicated that propolis of up to $200 \mu \mathrm{g} / \mathrm{ml}$ could stimulate the growth of normal cells. More studies showed that oxidative stress is a possible mechanism involved in apoptosis and necrosis induction. Increase level of reactive oxygen species (ROS) can affect cancer cells and lead to apoptosis and cell cycle arrest [39]. Accordingly, for evaluation of AEEP mechanism of action on ROS, we previously determined this mechanism on treated or untreated breast cancer cell line, MCF-7 via flow cytometry. Results shown that the levels of ROS increased significantly in MCF-7 cells in a dose-dependent manner compared with the control group. The observed results of ROS evaluation were accordance with cytotoxic activity on MCF-7 cells [40].

In previous studies on the impact of flavonoid quercetin on the oral squamous cell carcinoma (OSCC), it was found that $\mathrm{Q}$ inhibited the cell growth in a dosedependent way and induced apoptosis via the NF- $\mathrm{kB}$ pathway and inhibited the cell proliferation through G1-phase arrest and mitochondrial mediated apoptosis [30]. Another study evaluated the role of quercetin in inhibiting the growth and inducing apoptosis on MCF-7 cells and indicated that when $\mathrm{Q}$ was protected by nanostructures was more effective on the inhibition of MCF-7 proliferation by blocking the cell cycle and promoting apoptosis [17].

The findings suggested that AEEP and Q might have a chemo-preventive potential or act as an adjuvant therapeutic agent for tumor cells. Despite the fact that a number of reports indicated that specific compounds in propolis were responsible for their bioactivity against different diseases, other un-identified compounds in propolis could synergistically affect the bioactivity especially the inhibition of cancer cells and support of normal cells.

\section{Conclusion}

In summary, the obtained results indicated that AEEP and Q could efficiently inhibit oral streptococci through their antibacterial and cytotoxic effects on cancer cells lines, but it had no cytotoxic effects on normal cells. Since the North of Iran is reach in plants sources and local flora, which directly affect individual propolis components, it is highly recommended to look for mechanisms related to the antibacterial activity and inhibition of cancer cells by propolis and active ingredients in future studies.

\begin{abstract}
Abbreviations
AEEP: The ethanol extract of Iranian propolis from Ardabil origin; DMSO: Dimethyl sulfoxide; FBS: Fetal calf serum; HPLC: High-performance liquid chromatography; MBC: Minimum bactericidal concentration; MIC: Minimum inhibitory concentration; MSB: Mitis salivarius-bacitracin; MTT: 3-(4, 5-dimethylthiazolyl-2)-2, 5-diphenyltetrazolium bromide; PBS: Phosphate buffered saline; Q: Quercetin; SEM: Scanning electron microscopy; TYCSB: Trypticase yeast extract cysteine sucrose with bacitracin
\end{abstract}

\section{Acknowledgements \\ We would like to thank Ms. Pourbagher from Molecular and Cellular Biology Ressearch Center for help in conducting cytotoxicity assay experiment.}

\section{Authors' contributions}

FA, HRN and MM performed study design, supervised the experimental work literature search and wrote the manuscript; AEN performed the antimicrobial assays; EZ and HRN performed the cytotoxic assay and wrote the manuscript; HG carried out collection and interpretation of the data; AAM and SK performed HPLC experiments. HRN edited the manuscript. All authors read and approved the final manuscript carried out collection and interpretation of the data.

\section{Funding}

Deputy of Research of Babol University of Medical Sciences for funding the work through the research group project No 9441716.

\section{Availability of data and materials}

All data and materials of this work are available from the corresponding author on request.

\section{Ethics approval and consent to participate}

Not applicable.

\section{Consent for publication}

Not applicable.

\section{Competing interests}

The authors declare that they have no competing interests.

\section{Author details}

${ }^{1}$ Student Research Committee, Babol University of Medical Sciences, Babol, Iran. ${ }^{2}$ Dental Materials Research Center, Health Research Institute, Babol University of Medical Sciences, Babol, Iran. ${ }^{3}$ Department of Pharmacology, Faculty of Medicine, Babol University of Medical Sciences, Babol, Iran.

${ }^{4}$ Neuroscience Research Center, Health Research Institute, Babol University of Medical Sciences, Babol, Iran. ${ }^{5}$ Cellular and Molecular Biology Research Center, Health Research Institute, Babol University of Medical Sciences, Babol, Iran. ${ }^{6}$ Department of Microbiology, Faculty of Medicine, Babol University of Medical Sciences, Babol, Iran. ${ }^{7}$ Clinical Research Development Unit of Ayatollah Rohani Hospital, Babol University of Medical Sciences, Babol, Iran. ${ }^{8}$ Oral Health Research Center, Health Research Institute, Babol University of Medical Sciences, Babol, Iran.

Received: 10 September 2018 Accepted: 6 September 2019 Published online: 11 October 2019

\section{References}

1. Özan F, Sümer Z, Polat ZA, Er K, Özan Ü, Deḡer O. Effect of Mouthrinse containing Propolis on Oral microorganisms and human gingival fibroblasts. Eur J Dent. 2007;1:195-201.

2. VK S. Propolis in dentistry and oral cancer management. N Am J Med Sci. 2014;6:250-9.

3. Wagh VD. Propolis: a wonder bees product and its pharmacological potentials. Adv Pharmacol Sci. 2013;2013:11

4. Ahn MR, Kumazawa S, Hamasaka T, Bang KS, Nakayama T. Antioxidant activity and constituents of propolis collected in various areas of Korea. J Agric Food Chem. 2004;52:7286-92.

5. Bonamigo T, Campos JF, Alfredo TM, Balestieri JB, Cardoso CA, ParedesGamero EJ, et al. Antioxidant, cytotoxic, and toxic activities of Propolis from two native bees in Brazil: Scaptotrigona depilis and Melipona quadrifasciata anthidioides. Oxidative Med Cell Longev. 2017;2017:1038153. 
6. Elnakady YA, Rushdi Al, Franke R, Abutaha N, Ebaid H, Baabbad M, et al. Characteristics, chemical compositions and biological activities of propolis from Al-Bahah, Saudi Arabia. Sci Rep. 2017;7:41453.

7. Cavalcante DRR, Oliveira PSD, Góis SM, Soares AF, Cardoso JC, Padilha FF, et al. Effect of green propolis on oral epithelial dysplasia in rats. Braz J Otorhinolaryngol. 2011;77:278-84.

8. Wassel MO, Khattab MA. Antibacterial activity against Streptococcus mutans and inhibition of bacterial induced enamel demineralization of propolis, miswak, and chitosan nanoparticles based dental varnishes. J Adv Res. 2017:8:387-92.

9. Veloz JJ, Saavedra N, Lillo A, Alvear M, Barrientos L, Salazar LA. Antibiofilm activity of Chilean Propolis on Streptococcus mutans is influenced by the year of collection. Biomed Res Int. 2015;2015:6.

10. Gibbons RJ, Houte JV. Bacterial adherence in oral microbial ecology. Annu Rev Microbiol. 1975;29:19-44.

11. Cunha MG, Franchin M, de Carvalho Galvao LC, de Ruiz AL, de Carvalho JE, Ikegaki $M$, et al. Antimicrobial and antiproliferative activities of stingless bee Melipona scutellaris geopropolis. BMC Complement Altern Med. 2013;13:23.

12. Duarte $\mathrm{S}, \mathrm{Koo} H$, Bowen WH, Hayacibara MF, Cury JA, Ikegaki M, et al. Effect of a novel type of propolis and its chemical fractions on glucosyltransferases and on growth and adherence of mutans streptococci. Biol Pharm Bull. 2003;26:527-31

13. Hegde KS, Bhat SS, Rao A, Sain S. Effect of Propolis on Streptococcus mutans counts: an in vivo study. Int J Clin Pediatr Dent. 2013;6:22-5.

14. Jeon JG, Rosalen $\mathrm{PL}$, Falsetta $\mathrm{ML}$, Koo H. Natural products in caries research: current (limited) knowledge, challenges and future perspective. Caries Res. 2011;45:243-63.

15. Andrade JKS, Denadai M, de Oliveira CS, Nunes ML, Narain N. Evaluation of bioactive compounds potential and antioxidant activity of brown, green and red propolis from Brazilian northeast region. Food Res Int. 2017;101:129-38.

16. Pejin B, Ciric A, Markovic JD, Glamoclija J, Nikolic M, Stanimirovic B, et al. Quercetin potently reduces biofilm formation of the strain Pseudomonas aeruginosa PAO1 in vitro. Curr Pharm Biotechnol. 2015;16:733-7.

17. Ouyang J, Sun F, Feng W, Sun Y, Qiu X, Xiong L, et al. Quercetin is an effective inhibitor of quorum sensing, biofilm formation and virulence factors in Pseudomonas aeruginosa. J Appl Microbiol. 2016;120:966-74.

18. Lee JH, Park JH, Cho HS, Joo SW, Cho MH, Lee J. Anti-biofilm activities of quercetin and tannic acid against Staphylococcus aureus. Biofouling. 2013:29:491-9.

19. Vazquez-Armenta FJ, Bernal-Mercado AT, Tapia-Rodriguez MR, GonzalezAguilar GA, Lopez-Zavala AA, Martinez-Tellez MA, et al. Quercetin reduces adhesion and inhibits biofilm development by listeria monocytogenes by reducing the amount of extracellular proteins. Food Control. 2018;90:266-73.

20. Sankari SL, Babu NA, Rani V, Priyadharsini C, Masthan KM. Flavonoids clinical effects and applications in dentistry: a review. J Pharm Bioallied Sci. 2014;6:26-9.

21. Aghapour F, Moghadamnia AA, Nicolini A, Kani SNM, Barari L, Morakabati $P$, et al. Quercetin conjugated with silica nanoparticles inhibits tumor growth in MCF-7 breast cancer cell lines. Biochem Biophys Res Commun. 2018:500:860-5.

22. Ren KW, Li YH, Wu G, Ren JZ, Lu HB, Li ZM, et al. Quercetin nanoparticles display antitumor activity via proliferation inhibition and apoptosis induction in liver cancer cells. Int J Oncol. 2017;50:1299-311.

23. Falcão SI, Tomás A, Vale N, Gomes P, Freire C, Vilas-Boas M. Phenolic quantification and botanical origin of Portuguese propolis. Ind Crop Prod. 2013:49:805-12

24. CLSI. Performance standards for antimicrobial susceptibility testing; twentyfifth informational supplement; 2015. p. M100-S25.

25. Kouidhi B, Zmantar T, Bakhrouf A. Anti-cariogenic and anti-biofilms activity of Tunisian propolis extract and its potential protective effect against cancer cells proliferation. Anaerobe. 2010;16:566-71.

26. Hasan S, Singh K, Danisuddin M, Verma PK, Khan AU. Inhibition of major virulence pathways of Streptococcus mutans by quercitrin and deoxynojirimycin: a synergistic approach of infection control. PLoS One. 2014:9:e91736

27. Pandamooz S, Hadipour A, Akhavan-Niaki H, Pourghasem M, Abedian Z, Ardekani AM, et al. Short exposure to collagenase and coculture with mouse embryonic pancreas improve human dermal fibroblast culture. Biotechnol Appl Biochem. 2012;59:254-61

28. Liberio SA, Pereira AL, Araujo MJ, Dutra RP, Nascimento FR, Monteiro-Neto $V$, et al. The potential use of propolis as a cariostatic agent and its actions on mutans group streptococci. J Ethnopharmacol. 2009;125:1-9.
29. Sforcin JM, Bankova V. Propolis: is there a potential for the development of new drugs? J Ethnopharmacol. 2011;133:253-60.

30. Chen SF, Nien S, Wu CH, Liu CL, Chang YC, Lin YS. Reappraisal of the anticancer efficacy of quercetin in oral cancer cells. JCMA. 2013;76:146-52.

31. Gatto MT, Falcocchio S, Grippa E, Mazzanti G, Battinelli L, Nicolosi G, et al. Antimicrobial and anti-lipase activity of quercetin and its C2-C16 3-O-acylesters. Bioorg Med Chem. 2002;10:269-72.

32. Hayacibara MF, Koo H, Rosalen PL, Duarte S, Franco EM, Bowen WH, et al. In vitro and in vivo effects of isolated fractions of Brazilian propolis on caries development. J Ethnopharmacol. 2005;101:110-5.

33. Woznicka E, Kuzniar A, Nowak D, Nykiel E, Kopacz M, Gruszecka J, et al. Comparative study on the antibacterial activity of some flavonoids and their sulfonic derivatives. Acta Pol Pharm. 2013;70:567-71.

34. Baker CN, Thornsberry C. Antimicrobial susceptibility of Streptococcus mutans isolated from patients with endocarditis. Antimicrob Agents Chemother. 1974;5:268-71.

35. Machado CS, Mokochinski JB, de Lira TO, de Oliveira Fde C, Cardoso MV, Ferreira RG, et al. Comparative study of chemical composition and biological activity of yellow, green, Brown, and red Brazilian Propolis. eCAM. 2016;2016:6057650

36. Alizadeh AM, Afrouzan H, Dinparast-Djadid N, Sawaya AC, Azizian S, Hemmati HR, et al. Chemoprotection of MNNG-initiated gastric cancer in rats using Iranian propolis. Arch Iran Med. 2015;18:18-23.

37. Najafi MF, Vahedy F, Seyyedin M, Jomehzadeh HR, Bozary K. Effect of the water extracts of propolis on stimulation and inhibition of different cells. Cytotechnology. 2007:54:49-56.

38. Afrouzan H, Zakeri S, Abouie Mehrizi A, Molasalehi S, Tahghighi A, Shokrgozar MA, et al. Anti-Plasmodial assessment of four different Iranian Propolis extracts. Arch Iran Med. 2017;20:270-81.

39. Tsai YC, Wang YH, Liou CC, Lin YC, Huang H, Liu YC. Induction of oxidative DNA damage by flavonoids of propolis: its mechanism and implication about antioxidant capacity. Chem Res Toxicol. 2012;25:191-6.

40. Asgharpour F, Moghadamnia AA, Kazemi S, Nouri HR, Pouramir M, Mousavi SN, Motallebnejad M. Chemical composition analysis and In Vitro investigation of cytotoxic and Antioxidative activities of Iranian Propolis against breast Cancer cell line, MCF-7. ChemistrySelect. 2018;3:10857-63.

\section{Publisher's Note}

Springer Nature remains neutral with regard to jurisdictional claims in published maps and institutional affiliations.
Ready to submit your research? Choose BMC and benefit from:

- fast, convenient online submission

- thorough peer review by experienced researchers in your field

- rapid publication on acceptance

- support for research data, including large and complex data types

- gold Open Access which fosters wider collaboration and increased citations

- maximum visibility for your research: over $100 \mathrm{M}$ website views per year

At $\mathrm{BMC}$, research is always in progress.

Learn more biomedcentral.com/submissions 